\title{
Environmental and Social Accounting Practices, and Financial Performance of Cement Companies: Empirical Evidence from Nigeria
}

\author{
Okafor, Uchenna Israel ${ }^{1 *} \quad$ Oji, Richard Nduka ${ }^{2}$ Daferighe, Emmanuel Emeakponuzo ${ }^{3}$ \\ 1.Department of Accounting, University of Uyo, Nigeria \\ 2.Department of Entrepreneurship and Business Management, National Open University of Nigeria, Nigeria \\ 3.Department of Accounting, University of Uyo, Nigeria- Ph.D, accounting; 2018 World Champion, \\ Environmental Accounting
}

\begin{abstract}
Engaging in environmental and social activities and disclosing same in the annual financial or sustainability report by business entities has been controversial for over three decades among stakeholders across different industries. Therefore, the objective in the research was to test the empirical nexus of social investment cost (SIC) and environmental protection cost (EPC) in relation to financial performance of quoted cement companies in Nigeria. Financial performance was further denominated into sales turnover (ST) and market value of firms (MVF) to respectively develop two hypotheses in their alternative forms. While the researchers adopted ex poste facto research design, secondary data were obtained from relevant annual financial reports and database of the Nigerian stock exchange for 2009-2017. Descriptive statistics were utilized for data presentation before estimating the test result by adopting multivariate regression model. However, the test result for $\mathrm{H} 1$ indicated significant $\mathrm{P}$-value and F-value at $5 \%$ level of significance. In addition to accepting H1, positive Coefficients by SIC, EPC, and control variable (total assets-TA) demonstrated a strong adjusted R-square of $65.2483 \%$ association with ST, although, the coefficient for intercept was negative. Similarly, the test result for $\mathrm{H} 2$ also indicated significant $\mathrm{P}$-value and Fvalue at $5 \%$ level of significance. In addition to accepting $\mathrm{H} 2$, positive coefficients of intercept, EPC, and the control variable, market capitalization (MCAP) of cement companies in Nigeria cumulatively contributed a weak adjusted R-square of $25.213 \%$ to MVF. However, the coefficient for SIC was negative. Besides observing low level and inconsistent environmental and social accounting practices (ESAP) among cement companies in Nigeria, the researchers concluded that such insignificant level of ESAP by such companies influenced their financial performance. Hence, the researchers recommended cement companies to adopt ethical approach towards expanding investment in ESAP.

Keywords: Environmental and Social Accounting Practices, Corporate Social Responsibility Disclosures, Sustainability Reporting, Financial Performance, Accounting Measure of Financial Performance, Capital Market measure of Financial Performance
\end{abstract}

DOI: $10.7176 / \mathrm{EJBM} / 12-20-07$

Publication date:July $31^{\text {st }} 2020$

\section{Introduction}

Several researches across the world on Environmental and Social Accounting Practices (ESAP) alternatively known as Corporate Social Responsibility (CSR) disclosures or Sustainability Reporting (SR) have over the years demonstrated a mix of controversial and contradictory findings about their implications on firms' performance. Such dissenting results might have partly resulted from some neutralizing factors such as probable unreliable findings from studies in less environmentally and socially sensitive sectors, effects from short length of time series trend analyses, combined multi-sectoral regressions, multiple disclosure frameworks and measures of performance, reporting biases (green washing and impression management) among others. Precisely, there is no generally accepted global standard for ranking CSR practices and wide variety of performance indicators have also been adopted by researchers; thereby introducing ambiguity into different test results and their interpretations in this subject area. Whereas some researchers utilized financial measures of performance, others benchmarked their studies on non-financial measures. The financial measures of performance are classified into accounting (internal) performance indicators (such as return on equity (ROE), return on assets (ROA), sales turnover, and so on) and capital market(external) indicators (such as value of firm, changes in share prices, stock return among others). Moreover, non-financial measures include but not limited to customers' satisfaction, corporate reputation, mutual labour/management relations, recruitment and satisfaction of minority employee groups (such as women and disabled persons), quality of products and services. Irrespective of the choice of performance indices by different researchers, Elena, Lijuan and David (2017) supported by Dolores et al. (2019) suggested that the association between CSR and performance may become more objective, reliable, and comparable within the global outlook, if stratified and measured within the constraint of specific sectors, regions, types of disclosure, and different thresholds of organizations' sizes. 
Meanwhile, ESAP has been defined through a broad spectrum of CSR dimensions by various institutional and individual authors. Prominent among them is a definition by World Business Council for Sustainable Development (1999) which posits that "CSR is the continuing commitment by business to behave ethically and contribute to economic development while improving the quality of life of the work force and their families as well as of the local community and society at large". In a similar approach, Drucker (2001) cited in Ratner (2011) asserted that business organizations must show "...concern for the quality of life, that is, for the physical, human, and social environment of modern man and modern community". Holme and Watts (2000) described it as a continuous commitment by business entities to engage in certain roles in relation to environmental, social, and economic sustainability as they concern developing the society, improving the living condition of workforce and their families as well as the community at large. Another institutional definition by European Commission (2011) describes CSR as actions by companies over and above their legal obligations towards society and the environment. Related to that of EU Commission, Aaronson (2003) defined it as business decision making in compliance to ethical values or legal requirements in an effort towards social development and environmental sustainability. In a more generic sense, CSR is a combination of management activities which guide companies towards maximizing their positive impacts on their operating environment and the society; that is, "operating in a manner that meets and even exceeds the legal, ethical, commercial and public expectations of businesses", (McWilliams \& Siegel 2000). However, economic, social and environmental dimensions of CSR are the core of such management activities (Van Marrewijk 2003).

Drawing from the definitions, ESAP is evolving as one of the prominent issues in the global economy. A number of global, regional, sub-regional, national, institutional, and corporate entities are rapidly recognizing the importance of sustainability within the framework of growth and profitability of businesses, alongside other societal and environmental goals (Wilson 2003). For most business organizations, increasing adherence to sustainable practices may be attributable to factors such as pure philanthropy, ethical compliance, regulatory compliance, stakeholders' agitations and societal pressure, shopping for public reputation, expectation of financial returns among others (Lee \& Shin 2010). At global, regional, sub-regional, national, and institutional scale, environmental protection, social equality, and economic prosperity entrenched in ethical and legal frameworks are coincidentally the core principles of sustainable development. According to a Report by United Nations World Commission on Environment and Development, Brundtland (1987) describes sustainable development as "that which satisfies the needs of the present generation without compromising the ability of future generations to satisfy their own needs". Beyond this intergenerational framework of the report, the central sustainability roadmap is routed through social and environmental inclusion into the economic accountability of business entities. Considering the voluntary nature of sustainability practices in many territories however, most business entities, especially in the developing countries appear indifferent towards integrating such practices. Nonetheless, the current researchers speculate that any positive influence of CSR activities on corporate financial performance is capable of motivating more of such practices among hyper environmentally and socially sensitive sectors such as cement.

Moreover, the blooming of cement industry is often a desirable phenomenon in any economy due to its potential to satisfy crucial local demand and generate foreign exchange. Cement is globally an essential material for building and other civil engineering constructions. As such, it is a critical success factor for housing and other infrastructural needs of individuals, governments, and corporate entities. Thus, the reason for the extensive domestic and international demands for the product. Unfortunately, most operations of cement companies such as quarrying, crushing, grinding and blending, and packaging rank among major polluting and degrading activities to environmental components such as air, soil, water, vegetation, and so on (Kumar et al. 2008). In fact, the industry is one of the sources of particulate matter, carbondioxide, nitrogen oxides, sulfur dioxide emissions into the atmosphere (Syed et al. 2013). Dangote Cement (2016) confirmed that cement industry ranks second in carbondioxide emission after energy sector. Baby et al. (2008) reported that Cement dust contaminates the environment with heavy metals such as chro-mium, nickel, cobalt, lead, and mercury pollutants with negative impact on human and animal health. Baby et al. (2008) supported by Aydin et al. (2010) further asserted that Cement dust could cause carcinogenesis, decreased antioxidant capacity, acute respiratory disorders like lung function impairment, chronic obstructive lung diseases, restrictive lung diseases, pneumoconiosis and carcinoma of the lungs among others. Syed et Al. (2013) Found high prevalence of respiratory diseases, 97\% of eye irritations, and $95 \%$ of dermatological diseases among population living within 2 - 3 kilometers radius of cement companies. Therefore, it appears pertinent and ethical for cement manufacturing companies to engage in corporate social responsibility as a means of mitigating these negative externalities and improving the social and environmental wellbeing of their workforce and operating neighbourhood. Moreover, the going concern concept of cement companies is only attainable in an atmosphere of a wholesome planet and healthy people (environment, communities, customers, managers, employees, contractors, suppliers, etc.).

Against the foregoing background, it appears pertinent for firms operating in such socially and environmentally sensitive industry to disclose their CSR activities in the annual financial reports as a means of 
providing relevant information in utmost good faith to all stakeholders (Umoren, Isiavwe-Ogbari \& Atolagbe 2016), though the effect of such disclosure on corporate performance is still a debate among researchers and industry practitioners across the world. The issue of how best to integrate such financial and non-financial CSR information into the annual financial reports is nonetheless a major focus among different companies across the world, especially in the rising cases of public agitation for businesses to be environmentally and socially responsible in their operations. Despite the financial difficulties associated with measuring the exact negative impacts of some environmental and social activities on stakeholders, such as the indices of carbon and cement dust emission on human life, the lung diseases and cancers resulting from pollution, the number of lives lost due to toxic gas leakage from a company's plant among others (Daferighe 2010); it still appears value relevant to study the influence of spending on such concerns and their disclosures on firms' performance.

As some popular theories assume that CSR could be of value relevance to competitive business advantage, dissenting views and theories however argue that CSR is not only detrimental to competitiveness but also a disservice to the profit objective of investors. These divergent opinions are trailing different research-findings in the subject area across many industries; hence, suggesting the need for further studies. As a demonstration of such controversy, Akinlo and Iredele (2014) recorded that Environmental pollution and control policy, waste management cost and cost of compliance to environmental laws individually have a negative impact on the market value of firms in a study of 50 quoted companies in Nigeria; whereas Abdurrahman, (2014) found a statistically significant positive relationship between corporate social responsibility and total assets among quoted conglomerates in Nigeria. Findings by Asuquo, Temitayo and Raphael (2018) revealed that Economic, Environmental, and Social disclosures were insignificant with return on asset of selected breweries in Nigeria. In a contrast, a research by Adesunloro, Udeh and Abiahu (2019) revealed positive association between CSR and performance in Nigerian Brewery. Folajin, Ibitoye and Dunsin (2014) found that CSR spending inversely influence Net Profit in the short-term but speculated a better return in the long run. Considering the seeming causes of contradictory results and in adherence to the suggestion by Elena, Lijuan and David (2017), the objective in this study is to examine the relationship between the level of ESAP and financial performance of the cement industry in Nigeria for nine (9) years (2009-2017). The determinants for ESAP are social investment cost (SIC) and environmental protection cost (EPC); while the accounting and capital market measures of financial performance are respectively denominated as sales turnover and value of a firm determined through Tobin's Q model. Whereas Tobin-Q measure is a reflection of the investors' perspective of CSR activities on the value of cement firms, sales turnover is a reflection of their share of cement sales in response to CSR activities.

This paper started with an introduction in section one. The remaining sections are arranged as follows. Section two is literature review and hypotheses development. Whereas section three followed with operational method, section four is concerned with test of hypotheses and interpretations. Section five is the discussion of findings and section six is conclusion and recommendations.

\section{Literature Review and Hypotheses Development}

\subsection{Empirical Literature}

Despite a mix of controversial reports about the implementation and financial implications of engaging in corporate social responsibility by business entities across various industries in different territories, the apriori believe that CSR is of value relevance to all stakeholders remains dominant. Whereas most stakeholders in such school of thought benchmark their position on the morality and ethics of sustaining a wholesome society and environment for posterity, many researchers argue that engaging in CSR is capable of enhancing different performance indicators of business organisations. In the light of this overview, Abilasha and Tyagi (2019) investigated the impact of CSR on the financial performance of selected top 10 CSR performing Indian companies. With the primary aim of ascertaining the effect of CSR on corporate financial performance, profit before tax, return on capital employed, return on equity, and return on asset were used by the researchers as measures of performance. Data for the study were obtained from the annual and Sustainability Reports for 2014-17. Their findings revealed that all companies are on the average contributing about $2 \%$ of their income to CSR in line with Companies Act of India, 2013. These findings further indicated significant positive impact of CSR on financial performance of businesses. This however implies that financial performance increases as the firms contributes more to CSR, and vice-versa. Nonetheless, this outcome is not without dissenting argument from researchers in diverse industries. For instance, Asuquo, Temitayo and Raphael (2018) investigated the effect of sustainability reporting on performance of selected quoted breweries in Nigeria. Using ex-post facto research design, their data were obtained from financial statements of the three breweries in focus for five years (2012-2016). Return on Asset (ROA) was the dependent variable whereas Economic Performance disclosure, Environmental Performance disclosure, and Social Performance disclosure constituted the independent variables. However, their findings revealed that Economic, Environmental, and Social Performance disclosures were insignificant in relation to return on asset of selected breweries in Nigeria.

In strict adherence to the recommendation by Elena, Lijuan and David (2017) supported by Dolores et al. 
(2019) to measure the relationship between CSR and corporate performance within the constraint of specific sectors, regions, types of disclosure, and measures of organizations' sizes, the current researchers limit their study to cement industry of the Nigerian economy. Moreover, assessing the relationship between CSR and corporate financial performance within a specific sector was also extensively recommended in other previous studies (Griffin \& Mahon 1997; Moneva, Rivera-Lirio, \& Munoz-Torres 2007). These earlier researchers further posit that findings from companies sharing similar conditions and regulations will be more accurate and reliable.

To such extent, cement companies in Nigeria are similar in size due to standard requirement in terms of production equipment and machinery, besides operating in the same territory and regulations, using standard measure of packaging among others. In fact, cement companies in Nigeria are homogeneous in characteristics, regulatory framework, products, process, size, in addition to operating as hyper environmentally and socially sensitive firms in the same market. Whereas engaging in CSR activities may remain a debate in less or none environmentally sensitive industries, empirical evidences in support of such activities appear logically convincing for high environmentally sensitive and risky firms, such as cement factories. In addition to general industrial risks and hazards, Cumbane (2011) as cited in Çankaya and Taner (2015) summarised the Main hazardous factors specific to cement processing plants to include:

Quarrying -dust and noise;

Material input preparation - dust, toxic gas (CO, $\mathrm{CO} 2, \mathrm{NOx}, \mathrm{SO} 2)$, noise, and heat pollution;

Clinker burning - dust, toxic gas, high heat radiation, and high workload;

Clinker cooling and cement milling - auxiliary materials and additives, dust, heat, and noise;

Packaging, storage and delivery -dust, and high workload.

Assessing the health implications associated with the activities of Portland cement in polluted Khrew (site I) in comparison to non-polluted area of Burzahama and Jammu (control sites II), all in Kashmir, India, Syed et al., (2013) sampled particulate matter and trace gas between March and December, 2011. The parameters for the study included suspended particulate matter (SPM), respirable suspended particulate matter (RSPM), non-respirable suspended particulate matter (NRSPM), nitrogen oxides (NOx), and sulfur dioxide (SO2). Thus, the air temperature, air humidity, wind speed, wind direction, and light intensity were studied. The population for the study was derived from the none smokers living within 2 - 3kilometer radius of cement manufacturing zone (site I). Therefore, the researchers relied on questionnaire and interviews for data. Comparatively, the findings revealed that there was high level of air pollution with mean SO2 concentration of 115.2 microgramme $(\mu \mathrm{g}) / \mathrm{m} 3 \mathrm{in} \mathrm{site} \mathrm{I}$ and $28.13 \mu \mathrm{g} / \mathrm{m} 3$ in control site II. Similarly, NOx concentration in site I was $117.09 \mu \mathrm{g} / \mathrm{m} 3$ compared to the control site II where it was $19.46 \mu \mathrm{g} / \mathrm{m} 3$. This result is indicative of high prevalence of diseases especially respiratory disorders; about $97 \%$ and $95 \%$ respectively also suffered eye irritations and dermatological disorders among the population within site I. A further assessment of oxidative and nitrosative stress among the population within site I were quantified by reactive oxygen species (ROS) and nitric oxide (NO) levels in serum of subjects and results revealed that there was high level of air pollution, risk health factors, over production of nitrogen species as well as ROS in people living around the cement factory. Considering these environmental and social risks associated with cement manufacturing activities, an unconditional engagement in CSR activities and reporting same by such companies appears ethically rational and imperative. However, that may not currently be attainable in most developing countries due to poor legal basis of CSR practices in different territories as well as the voluntary nature of most sustainability reporting frameworks. Nonetheless, a positive association between CSR practices and corporate performance could motivate cement companies to engage in such activities.

Arguing that the underlying rationale for CSR by corporate entities is to win the trust of the stakeholders through attention to the environmental and social needs of their neighbourhood communities, Patil and Sawant (2014) noted a heavy environmental footprint in the cement production process. However, the researchers focused on investigating the level of CSR practices in terms of indicators and cost by big select cement companies of the Indian economy. Relying on annual and sustainability reports for generating secondary data, they adopted ANOVA two factor without Replication for estimating their test result. Their findings revealed that the Cement companies under study were ethically committed to their stakeholders by conducting their businesses in economically, socially and environmentally sustainable and transparent manner. Specifically, the CSR impact on all selected companies were most significant in welfare programmes, such as health \& family care programs, community infrastructural projects, contribution to religious and social activities, promoting cultural heritage, women empowerment schemes, educational support schemes, agricultural development programmes among others.

In another exploration of the relationship between CSR \& financial performance, Munaza et al. (2013) examined 15 companies including cement factories, which are listed on Karachi stock exchange of Pakistan. Adopting correlation analysis for estimating the cause and effect of the relationship, the findings of the study revealed a considerable positive relationship between CSR and Financial performance of the firms. The researchers moreover underscored that expenditure on CSR was not only for long term sustainable development but also for the enhancement of short-term financial performance. Lending credibility to these earlier researchers, Bafna (2017) asserted that increased expenditure on corporate social responsibility impacts positively on profitability of 
businesses which further converts into sustainable development of business organisations and the society at large. In consonance with Bafna (2017), Beiting Cheng (2018) also suggested firms to be strategic in their CSR for long term sustainability, better access to finance and mitigation to capital constraint, better stakeholders' engagement, and reporting transparency.

Similarly, Majid and Abdul (2013) aimed to examine the relationship between corporate social responsibility, Profitability, and market share in Pakistan. Survey method through questionnaire was used for data collection and Cross correlation technique adopted for analyses. CSR dimensions were further segmented into environmentrelated responsibilities, customer-related responsibilities, community-related responsibilities, and legal-related responsibilities; and the relationship of each tested against profitability and market share in terms of turnover. Findings however revealed significant relationship between CSR and profitability through market share. Therefore, the researchers suggested managers of business entities to constantly communicate their CSR programmes to customers and other stakeholders as a means of increasing their market turnover.

Highlighting the strategic importance of CSR as a core source of operating benefit and enhanced societal integration for businesses, Ghafoor and Akhtar (2014) investigated the contribution of Corporate Social Responsibility to profitability of Fertilizer \& Cement companies in Pakistan. The researchers obtained cross sectional primary data from the executive cadre of the surveyed organisations in addition to adopting descriptive statistical tools for data analyses. The relationship between CSR and corporate performance was estimated through a multiple regression model. However, findings indicated that implementing CSR is pivotal to brand awareness and reputation enhancement among the customers; thus, demonstrated significant positive association with profitability. The researchers hence suggested improvement in CSR practices by the companies for boost in profitability.

A related research by Murtala (2017) probed into the relationship between corporate social responsibility (CSR) investment and corporate performance of Dangote Cement Plc. Moreover, the determinants for corporate performance in the study were revenue, profit after tax (PAT), and earnings per share (EPS) over a period of 5years (2012-2016). Secondary data were used for the study and the indices for CSR investment were obtained from the annual sustainability reports and accounts for the relevant years. Descriptive statistical tools such as tables and percentages were used for data summary and presentation before tracing the trend line analysis to estimate the linear correlation coefficient (R-square). However, findings revealed a positive relationship between CSR investment and corporate performance. A further breakdown of the result indicated $67.81 \%, 54.28 \%$, and $60.79 \%$ levels of positive associations between CSR and revenue, profit after tax, and earnings per share respectively. Hence, the researcher generalized that the CSR investment of Dangote Cement Plc is positively correlated with its corporate performance indicators.

Majid et al. (2013) also examined the relationship between corporate social responsibility and corporate reputation in the cement companies of Pakistan. Utilizing survey design and adopting questionnaire for data collection, the researchers studied four dimensions of CSR: environment related responsibilities, customer related responsibilities, community related responsibilities, and legal responsibilities. Inferential statistics was applied for data analysis and the result revealed a strong positive association between CSR and corporate reputation in cement industry of Pakistan. Thus, demonstrating agreement with the study by Munaza, Farida, Shagufta, and Shahid (2013). Although reputation is a non-financial indicator of corporate performance, there is a nexus between good corporate image and financial performance of business entities.

In a case study of Ashaka cement company, Ado (2013) analyzed the role of business organizations in promoting sustainable development within their host communities through CSR activities. Among others, the researcher aimed to investigate the strategies adopted by Ashaka Cement Company towards CSR implementation, the nature of relationship between the company and host communities, the specific contributions of the company towards developing the communities. Whereas the researcher depended on questionnaire and interview as instruments for obtaining relevant data, descriptive statistics were used for their analyses. A significant positive association was found between grievances in the Ashaka communities and the CSR activities of the company. This implies that the CSR performance of the company was far below the expectations of the communities. Thus, the researcher recommended viable CSR programmes that could significantly impact on the communities. That was expected to improve their community relationship and cooperation, peaceful operating environment, and ultimately their reputation and performance through profitability.

From another dimension of CSR studies, Mohammed, Ali and Zahra'u (2019) examined the effect of profitability, firm size, and dividend on CSR performance of listed Cement firms in Nigeria for the period (20122016). Obtaining secondary data from the annual financial reports of the selected firms, the researchers adopted multiple regression technique for estimating the test results. Their findings revealed that profitability, firm size and dividend paid positively and significantly influence the CSR practices of listed Cement firms in Nigeria. Therefore, the researchers recommended the management to always strive for improvement in profitability, expansion of the firm's assets base, and consistent dividend payment as preconditions for CSR practices. This outcome further suggests a symbiotic and bi-directional association between CSR and corporate performance as 
complemented in other reviewed researches. Underscoring the long-range duration of time required to establish this positive relationship, the researchers however noted that the long-term interest of a business is more important than any size of short-term profitability.

\subsection{Theoretical Background \\ i Stakeholder Theory}

Despite the dearth of related prior researches observed in this review concerning cement companies in Nigeria, their operations and activities still affect different classes of people, communities, employees, organisations, governments, and other interest groups herein referred to as stakeholders. However, the reaction of the stakeholders may also influence the smooth operation and performance of cement companies. Freeman et al. (2010) described stakeholders as groups and individuals whose stakes and their management are crucial to the success or failure of business entities. Moreover, stakeholder theory primarily suggests companies to positively offset their negative externalities on the stakeholders. This underscores the importance of the theory to cement industry with numerous negative environmental and social imprints. Introduced in 1984 by Edward Freeman, the background philosophy of stakeholder theory is that satisfying different segments of the stakeholders in compensation for their negative impacts or as good corporate citizen and good neighbor can return a long-term economic benefit to business entities. Vladislav, Steffen and Matthias (2019) further described stakeholder theory as an influential modern approach to strategic management. In another perspective, Al-Amosh and Mansor, (2018) remarked that Stakeholder theory is about the need for management to satisfy or at least positively influence the aspirations and expectations of the stakeholders including transparent reporting in their effort towards the organizational goals.

Kang, Lee and Huh, (2010), supported by Lee, Seo and Sharma (2013) highlighted the value relevance of environmental and social responsibilities by companies towards their reputation. Genuine concern towards the expectations of stakeholders by business entities is capable of improving their acceptability and reducing the cost of publicity and attracting investors to their stocks and securities, alongside the ease of managing different community concerns and accessing credit facilities. This theory summarily suggests that CSR activities smoothen relationship between companies and their essential constituencies, including but not limited to banks, investors, customers, host communities, and governmental agencies. Adding to mitigating their hazardous operations therefore, cement companies in Nigeria may also adopt CSR as a strategy for enhancing their reputation, cordial relationship with their essential constituencies, and ultimately their financial performance.

ii Triple Bottom Line (TBL) Theory

Depletion, degradation, and degeneration of social and environmental capital is conventionally linked to the activities of some companies including cement. Unfortunately, such is also a threat to the "going concern" of such companies as unwholesome planet and unhealthy people negate the performance progress of business entities. Therefore, the triple bottom line theory suggests financial provision by firms for the maintenance of sustainable environment, society, and ultimately profitability. The founding theorist, Elkington (2000) asserted that a firm is sustainable only if it operates in tandem with 'Triple Bottom Line' principles (economic prosperity, environmental protection, and social justice). As a win-win practice for all, TBL emphasizes the importance of sustainability practices by estimating the impact of organizations' activities on their operating environment, society, and their very own corporate performance, including quality of profitability and other shareholders' values. Thus, the TBL is an accounting framework that fragments corporate performance into social, environmental and economic segments.

In accordance with its primary focus on social, environment, and economic dimensions, the TBL is respectively referred to as the 3 Ps denoting people, planet, and profit. The exponents of triple bottom line posit that well-being of the planet and people are pre-conditions for a sustainable profit. From ethical perspective however, environmental quality and social justice supersede economic prosperity in the magnitude of importance within the context of TBL. To this extent, any business that cannot compensate for its operational contribution to environmental degradation, natural assets depletion, and social risks is not yet profitable, because all costs are not fully paid. Therefore, such business may need to embark on a strategic research towards profitability benchmarked on sustainability practices. Hence, the association between CSR and corporate financial performance is adequately explainable through TBL theory. Moreover, this theory has been successfully adopted in prior CSR researches (Hollos, Blome \& Foerstl 2012; Sapukotanage, Warnakulasuriya \& Yapa 2018).

\subsection{Hypotheses Development}

In tandem with many prior empirical results, popular theoretical philosophies, and predominant apriori expectation, the researchers formulated the following hypotheses to further investigate the objective of the study:

H1: Sales turnover of cement companies in Nigeria is significantly associated with their levels of social investment cost and environmental protection cost.

H2: Capital market value of cement firms in Nigeria is significantly associated with their levels of social investment cost and environmental protection cost. 


\section{Operational Method}

3.1 Research Design

Ex post facto research design was adopted for obtaining historical accounting and capital market data of relevant cement companies in Nigeria. Content analysis of the annual financial reports and the database of Nigerian Stock Exchange (NSE) was specifically adopted for obtaining relevant panel data for estimating environmental and social accounting practices as well as performance indices of the companies for a period of 9 years, (2009-2017). Moreover, the population for the study comprises five (5) cement companies which operated or are still operating as independent business entities and were or are still quoted on the NSE. They include Lafarge cement Plc, Dangote cement Plc, Ashaka cement Plc, Cement company of Northern Nigeria Plc, and BUA cement Plc. However, Ashaka cement Plc was acquired by Lafarge cement Plc in 2018 while Cement company of northern Nigeria Plc was lately acquired by BUA cement Plc in 2019. Nevertheless, Cement company of northern Nigeria Plc and BUA cement Plc were eliminated from the empirical investigation due to their inadequacy in providing requisite data for analysis. Therefore, the remaining three (3) cement companies constituted the sample for this study within the time frame they were all listed on the NSE and raised annual financial reports as separate business entities.

\subsection{Empirical Model and Definition of Variables}

Two multivariate regressions are utilized to estimate the association between the key variables in this study. Their equations are:

$$
\begin{aligned}
& \mathrm{ST}_{i},=\beta_{0 i},+\beta_{1} \mathrm{SIC}_{i},+\beta_{2} \mathrm{EPC}_{i},+\beta_{3} \mathrm{TA}_{i},+\varepsilon_{i},-\cdot-\cdot--\cdot-\cdot----\cdot---(3 . \mathrm{i}) \\
& \mathrm{MVF}_{i},=\beta_{0 i},+\beta_{1} \mathrm{SIC}_{i},+\beta_{2} \mathrm{EPC}_{i},+\beta_{3} \mathrm{MCAP}_{i},+\varepsilon,
\end{aligned}
$$

Whereas equation (3.i) is for estimating the influence of ESAP on the accounting performance of cement companies in Nigeria, equation (3.ii) measures their capital market performance. Moreover, the variables in the equations are denoted as follows:

Dependent Variables

There are two dependent variables for testing the implications of environmental and social accounting practices on accounting and market performance of cement companies in Nigeria and for estimating the predictions in $\mathrm{H} 1$ and $\mathrm{H} 2$ respectively. They include Sales Turnover (ST) and market value of a firm (MVF) computed through Tobin's Q model. Pereira V. and Filipe J. (2014) however suggested a combination of both accounting and market measures of financial performance for more reliable findings. However, the tobin's q model is stated as:

$\mathrm{MVF}=\quad$ Market Value of total Equity + Total Book Value of all Liabilities Total Assets

\section{Independent Variables}

The primary determinants for ESAP are social investment cost (SIC) and environmental protection cost (EPC). Both are however applied in equation (3.i) and (3.ii) for ascertaining their respective influence on accounting and capital market performance of cement companies in Nigeria.

Control Variables

total assets (TA)And market capitalization (MCAP) were respectively adopted for measuring the effect of size and influence on accounting and market performance of cement firms in Nigeria. Moreover, the basic assumption in prior literature is that financial performance may be correlated with firms' size (McWilliams \& Siegel 2001). Hence, the need to isolate the possible influence of size from those of SIC and EPC.

Other Denotations

$i=$ specific company (ith company) in the numeric series of companies under review;

$t=$ specific period of time (year) in the time series of the analysis;

$\varepsilon=$ stochastic.

\section{Test of Hypotheses and Interpretations}

4.1 Test of Hypothesis One

H1: Sales turnover of cement companies in Nigeria is significantly associated with their levels of social investment cost and environmental protection cost.

The panel data in Table 4.1 of the Appendix are utilized for analysing this hypothesis by applying regression model in equation 3.i. Moreover, statistical package for the social sciences (SPSS) was adopted for estimating the test result of the regression. 
Table 4.3 Estimation of the multiplicative influence of Intercept, SIC, EPC, and TA on ST

\begin{tabular}{lr}
\hline \multicolumn{2}{c}{ Regression Statistics } \\
\hline Multiple R & 0.832214 \\
R Square & 0.692581 \\
Adjusted R Square & 0.652483 \\
Standard Error & 71717753 \\
Observations & 27 \\
\hline
\end{tabular}

Source: SPSS Test Result, 2020

Table 4.4 Anova for Testing the Significance of the General Regression Model

\begin{tabular}{lccccc}
\hline & $d f$ & $S S$ & $M S$ & $F$ & $P$-value \\
\hline Regression & 3 & $2.67 \mathrm{E}+17$ & $8.88 \mathrm{E}+16$ & 17.27214 & $4.3 * 10^{-6}$ \\
Residual & 23 & $1.18 \mathrm{E}+17$ & $5.14 \mathrm{E}+15$ & & \\
Total & 26 & $3.85 \mathrm{E}+17$ & & & \\
\hline
\end{tabular}

Source: SPSS Test Result, 2020

Table 4.5Estimation of the Isolated Contributions of Intercept, SIC, EPC, and TA to the cumulative behaviour of ST

\begin{tabular}{lrrrrrrrr}
\hline & Coefficients & Standard Error & \multicolumn{1}{c}{ S Stat } & P-value & Lower 95\% & Upper 95\% & Lower 95.0\% & Upper 95.0\% \\
\hline Intercept & -2786924 & 20629383 & -0.13509 & 0.893712 & $-4.5 \mathrm{E}+07$ & 39888206 & $-4.5 \mathrm{E}+07$ & 39888206.16 \\
SIC & 0.079164 & 0.042015 & 1.884213 & 0.072238 & -0.00775 & 0.166078 & -0.00775 & 0.166078033 \\
EPC & 0.266275 & 0.082331 & 3.234207 & 0.003666 & 0.095961 & 0.436589 & 0.095961 & 0.436589475 \\
TA & 0.228835 & 0.057304 & 3.993336 & 0.000572 & 0.110292 & 0.347378 & 0.110292 & 0.347377717 \\
\hline
\end{tabular}

Source: SPSS Test Result, 2020

Estimates of the general model in Table 4.4 indicated that the P-value of 0.0000043 is less than 0.05 level of significance and the calculated F-value of 17.27214 is greater than the critical F-value of 3.03 at $5 \%$ level of significance. Hence, the alternative hypothesis (H1) is accepted. In congruence with the outcome, social investment cost (SIC), environmental protection cost (EPC), and total assets (TA) demonstrated a strong joint positive relationship with the behavioural pattern in sales turnover (ST) as indicated in the adjusted R-square of $65.2483 \%$ in table 4.3. As shown in Table 4.5 however, the individual regression coefficient contributions to ST resulting from a unit change in intercept, SIC, EPC, or TA while holding other parameters of the regression constant are respectively $-27.86924 \%, 7.9164 \%, 26.6275 \%$, and $22.8835 \%$. Whereas the P-values of EPC and TA are less than 0.05 levels of significance, those of intercept and SIC are greater than 0.05 levels of significance, as also revealed in Table 4.5. Though SIC, EPC, and TA indicated varying extents of positive coefficients, the comparatively more significant coefficient contributions by EPC and TA in addition to their statistically significant P-values might have largely influenced the F-statistic in the model, which informed the acceptance of the alternative hypothesis (H1).

\subsection{Test of Hypothesis Two}

$\mathrm{H} 2$ : Capital market value of cement firms in Nigeria is significantly associated with their levels of social investment cost and environmental protection cost.

Panel data in Table 4.2 in the Appendix are utilized for analysing this hypothesis by applying the regression model in equation 3.ii. Moreover, statistical package for the social sciences (SPSS) was utilized for estimating the test result of the regression.

Table 4.6 Estimation of the multiplicative influence of Intercept, SIC, EPC, and MCAP on MVF

\begin{tabular}{lr}
\hline & \\
\hline Multiple R & Regression Statistics \\
R Square & 0.581741 \\
Adjusted R Square & 0.338423 \\
Standard Error & 0.25213 \\
Observations & 0.105399 \\
\hline
\end{tabular}

Source: SPSS Test Result, 2020

Table 4.7 Anova for Testing the Significance of the General Regression Model

\begin{tabular}{lccccc}
\hline & $d f$ & $S S$ & $M S$ & $F$ & $P$-value \\
\hline Regression & 3 & 0.130701 & 0.043567 & 3.921799 & 0.021318 \\
Residual & 23 & 0.255506 & 0.011109 & & \\
Total & 26 & 0.386207 & & & \\
\hline
\end{tabular}

Source: SPSS Test Result, 2020 
Table 4.8 Estimation of the Isolated Contributions of Intercept, SIC, EPC, and MCAP to the cumulative behaviour of MVF

\begin{tabular}{lrrrrrrrr} 
& Coefficients & Standard Error & \multicolumn{1}{c}{$t$ Stat } & P-value & Lower 95\% & Upper 95\% & Lower 95.0\% & Upper 95.0\% \\
\hline Intercept & 0.357922 & 0.035562 & 10.06474 & $6.77 * 10^{-10}$ & 0.284357 & 0.431488 & 0.284357 & 0.431488 \\
SIC & $-7.5 * 10^{-11}$ & $6.4 \mathrm{E}-11$ & -1.16992 & 0.254012 & $-2.1 \mathrm{E}-10$ & $5.75 \mathrm{E}-11$ & $-2.1 \mathrm{E}-10$ & $5.75 \mathrm{E}-11$ \\
EPC & $1.79 * 10^{-10}$ & $1.2 \mathrm{E}-10$ & 1.494615 & 0.148609 & $-6.9 \mathrm{E}-11$ & $4.26 \mathrm{E}-10$ & $-6.9 \mathrm{E}-11$ & $4.26 \mathrm{E}-10$ \\
MCAP & $4.39 * 10^{-13}$ & $1.78 \mathrm{E}-13$ & 2.468263 & 0.02144 & $7.1 \mathrm{E}-14$ & $8.06 \mathrm{E}-13$ & $7.1 \mathrm{E}-14$ & $8.06 \mathrm{E}-13$ \\
\hline
\end{tabular}

Source: SPSS Test Result, 2020

Test of the general model in Table 4.7 revealed a P-value of less than 0.05 level of significance and a calculated F-value of 3.921799, which is greater than the critical F-value of 3.03 at 5\% level of significance. Therefore, the alternative hypothesis (H2) is accepted. Nonetheless the significant outcome, Table 4.6 indicated a weak multiplicative positive adjusted R-square of $25.213 \%$ as the joint contributions from intercept, social investment cost (SIC), environmental protection cost (EPC), and market capitalization of firms (MCAP) in relation to the performance of market value of firms (MVF). With an exception of the intercept, the isolated regression coefficient contributions to MVF resulting from a unit change in SIC, EPC, or MCAP while holding other regression parameters constant are respectively negative, insignificantly positive, and insignificantly positive at varying extents of $-0.0000000075 \%, 0.0000000179 \%$, and $0.0000000000439 \%$, as indicated in Table 4.8 . Although, the regression coefficient of the intercept is mathematically significant at $35.7922 \%$, it is of little importance in the analysis since market value of firms cannot be influenced by only the intercept, when the other regression parameters are zero or held constant. However, the P-values for SIC and EPC shown in Table 4.8 are greater than 0.05 levels of significance, whereas those of intercept and MCAP in the same Table are less than 0.05 levels of significance. This simply implies that the significance of the general test model observed in F-statistic and P-value in Table 4.7 can be largely attributable to MCAP and intercept. Adding to the insignificant positive coefficient of EPC, the P-values of SIC and EPC are statistically insignificant in predicting the behavioural pattern of market value of cement firms in Nigeria.

\section{Discussion of Findings}

Accepting the alternative hypothesis (H1) is an empirical evidence of a positive interactive nexus between sales turnover and levels of environmental and social accounting practices (ESAP) of cement companies in Nigeria. This decision was informed by the statistical significance of F-value and P-value of the general regression model in Table 4.4. The outcome is in consonance with popular apriori expectation and in convergence with some earlier researches in cement and other industries. For instance, Majid and Abdul (2013) in Pakistan and Murtala (2017) in Nigeria specifically found positive association between social and environmental accounting practices and profitability, respectively measured by the researchers through share of product sales and revenue. Majid and Abdul (2013) further recommended managers of business organizations to constantly communicate their CSR programmes to customers and other stakeholders as a strategy for increasing their sales turnover. Although, both social investment cost (SIC) and environmental protection cost (EPC) contributed to sales turnover (ST) as shown by their positive coefficients in Table 4.5, EPC further demonstrated statistically significant P-value in the same Table. As firms dealing on construction materials in relation to the outcome of EPC, investment in environmental protection may have been more rewarding in terms of sales return than social investment for cement companies. Moreover, as a cost control technique or cash management strategy, the cost incurred by cement companies on environmental protection activities may not be in cash or cash equivalent but product based, such as contributing cement to remedy public environmental problems.

Highlighting the importance of SIC however, Ado (2013) linked the grievances and agitation by host communities of Ashaka cement company to poor CSR by the company, hence, recommended enhancing community relationship and cooperation as means of ensuring peaceful operating environment, reputation management, and ultimately good financial performance. In tandem with the popular apriori expectation, the empirical result in the test of hypothesis two also demonstrated a positive association between ESAP and capital market value of cement companies in Nigeria. Thus, resulting to the acceptance of the alternative hypothesis (H2). Nonetheless the statistical significance of F-value and P-value of the general regression model in Table 4.7, ESAP variables indicated to have contributed insignificantly to such outcome. SIC and EPC respectively revealed negative and insignificant positive contributions in their regression coefficients, as shown in Table 4.8. Nevertheless the inconsistency of this result with most reviewed researches on cement industry, Asuquo, Temitayo \&Raphael (2018) found that social and environmental performance disclosures were insignificant in relation to return on asset, though among selected breweries in Nigeria. Arguing in divergence to the test result but in favour of popular social and environmental accounting theories and dominant apriori philosophies, the outcome might have resulted from poor level of CSR activities and/or their inadequate accounting disclosures by cement companies in Nigeria, which may have also caused poor visibility of the firms to capital market investors. It could 
also be that such investors are only interested in profit maximization at the expense of any other business-value, including a healthy society and a wholesome planet, which are also crucial to the progress of going concern principle of their investment. In a related dimension, cement companies in Nigeria may simply be engaging in greenwashing, impression management, and earnings management which cannot translate into business-value capable of attracting investors.

Comparatively, environmental and social accounting practices (ESAP) influenced accounting financial performance more than capital market financial performance of cement firms in Nigeria. Thus, implying that SIC and EPC jointly dictate the patronage pattern of cement buyers than the decision pattern of capital market investors in cement companies, as shown in their effects on ST and MVF in the analyses. In their control for the effect of size and influence on the financial performance of cement companies in Nigeria however, total assets (TA) and market capitalization (MCAP) are statistically significant in the tests of hypotheses one and two. As shown in Tables 4.5 and 4.8 , both respectively revealed positive regression coefficients in the analyses. They are also statistically significant in Tables 4.5 and 4.8 respectively, with P-values of less than 0.05 levels of significance. This finding is in congruence with the assertions by McWilliams and Siegel (2001) that financial performance may be correlated with firms' size.

\section{Conclusion and Recommendations}

The researchers concluded that the levels of environmental and social accounting practices by cement companies in Nigeria positively influenced their financial performance, as revealed in adjusted R-squares of $65.2483 \%$ in Table 4.3 and $25.213 \%$ in Table 4.6 from the test results of $\mathrm{H} 1$ and $\mathrm{H} 2$ respectively. In other words, variation in the level of ESAP is capable of predicting the behavioural pattern of financial performance of cement companies in Nigeria. Therefore, the outcome lends empirical credibility to the findings in earlier studies by Munaza et al. (2013), Majid and Abdul (2013), Ghafoor and Akhtar (2014), and Murtala (2017). Due to voluntary nature of adopting such practices perhaps, the researchers also observed that the level of ESAP by cement companies in Nigeria are not only generally low but also inconsistent across the reviewed years. If such low level can result into positive influence on financial performance, then, environmental and social accounting practices still reserves a robust potential for financial improvement of cement companies in Nigeria. Moreover, considering the hyper social and environmental negative externalities associated with the activities of cement companies, it was recommended that such companies:

- Should expand investment in social and environmental concerns besides ensuring their adequate disclosure in the annual financial or sustainability report. This could unequivocally establish the association between ESAP and financial performance of cement companies in Nigeria.

- Should adopt ethical approach towards ESAP, considering the hazardous and risky nature of their activities to the environment and society at large.

- Should enhance their going concern philosophy, since no company can exist for an unforeseeable future time without a healthy society and a wholesome planet.

\section{References}

Aaronson, S 2003, 'Corporate responsibility in the global village: The British role model and the American laggard', Business and Society Review, vol. 108 no. 3, pp. 309-318.

Abdurrahman, S 2014, 'The influence of corporate social responsibility on total assets of quoted conglomerates in Nigeria', Journal of Business Administration and Management Sciences Research, vol. 3, no. 1, pp. 12-21.

Abilasha, N \& Tyagi, M 2019, 'Impact of CSR on Financial Performance of Top 10 Performing CSR Companies in India', PhD Dissertation, School of Management Studies, Indira Gandhi National Open University, New Delhi, India.

Adesunloro, B, Udeh, F \& Abiahu, M 2019, 'Corporate social responsibility reporting and financial performance: A study of Nigerian breweries plc', Archives of Business Research, vol. 7, no. 4, pp. 45-57.

Ado U 2013, 'Politics and corporate social responsibility: A study of the Ashaka cement company plc in Gombe state (1999-2009', Journal of Research in National Development, vol. 11, no. 2, pp. 95-104.

Akinlo, O \& Iredele, O 2014, 'Corporate environmental disclosures and market value of quoted companies in Nigeria', The Business \& Management Review, vol. 5, no. 3, pp. 171-184.

Al-Amosh, H \& Mansor, N 2018, 'Sustainability and corporate reporting: A review on environmental and social accounting disclosure: A conceptual paper, International Journal of Accounting, Finance and Business, vol. 3, no. 8, pp. 78-87.

Asuquo, A, Temitayo, D \& Raphael, O 2018, 'The effect of sustainability reporting on corporate performance of selected quoted brewery firms in Nigeria', International Journal of Business \& Law Research, vol. 6, no. 3, pp. $1-10$

Aydin, S, Aydin, S, Croteau, G, Sahin, I \& Citil, C 2010, 'Ghrelin, nitrite and Paraoxonase/Arylesterase concentrations in cement plant workers', Journal of Medical Biochemistry, vol. 29, no. 2, pp. 78-83. 
Baby, S, Singh, N, Shrivastava, P, Nath, S, Kumar, S, Singh, D \& Vivek K 2008, 'Impact of dust emission on plant vegetation of vicinity of cement plant', Environmental Engineering and Management Journal, vol. 7, no. $1, \mathrm{pp} .31-35$.

Bafna, A 2017, 'A study on the impact of csr on financial performance of companies in India', International Journal of Engineering Technology, Science and Research, vol. 4 , no. 12, pp. 325-331.

Beiting cheng, L 2011, 'Corporate Social Responsibility and Access to Finance', Strategic Management Journal, vol. 35 , no. 1 , pp. 1-23.

Brundtland, G 1987, 'Our Common Future', United Nations World Commission on Environment and Development (Brundtland Commission), Oxford University Press, Oxford.

Çankaya, S \& Taner Ç 2015, 'Occupational health and safety in cement industry', Journal of International Scientific Publications, vol. 9, pp. 243-250.

Daferighe, E 2010, 'Environmental accounting and degradation', A Quarterly Journal of Association of National Accountants of Nigeria, vol. 18, no. 4, pp. 55-65.

Dangote Cement 2016, Annual reports, Dangote cement, viewed 21 January 2020, $<\mathrm{http}: / / \mathrm{www}$.dangotecement.com/wpcontent/uploads/reports/2019/Q1/DangoteCementPlc_2018_AnnualReport.pdf>

Dolores, G, María, J, María, L \& Julio S 2019, 'Corporate Social Responsibility Disclosure and Performance: A Meta-Analytic Approach', Sustainability, vol. 11, no. 4, pp. 1-33.

Elena, M, Lijuan, Z \& David C 2017, 'Issues in sustainability accounting reporting', Accounting and Finance Research, vol. 6, no. 3, pp. 64-71.

Elkington, J 2000, 'Cannibals with forks: The Triple Bottom Line of 21 st Century Business', Journal of Business Ethics, vol. 23, no. 2, pp. 229-231.

Environmental Protection Agency (EPA) 1994, Emission factor documentation for AP-42, section 11.6: Portland Cement Manufacturing, Final report EPA Contract 68-D2-0159, MRI Project No. 4601-01, Environmental Protection Agency, $\quad$ viewed 4020 , $<$ https://www.lm.doe.gov/cercla/documents/rockyflats docs/IA/IA-A-003002.PDF>

European commission. (2011, October 25). A renewed EU strategy 2011-14 for corporate social responsibility. Communication from the commission to the European Parliament, the council, the European economic and social committee and the committee of the regions. Brussels: European commission. http://eurlex.europa.eu/LexUriServ/LexUriServ.do?uri=COM:201 1:0681:FIN:EN:PDF. (Retrieved on 6 ${ }^{\text {th }}$ October, 2019).

Folajin, O, Ibitoye, O \& Dunsin, A 2014, 'Corporate social responsibility and organizational profitability: An empirical investigation of United Bank for Africa (UBA) Plc', International Journal of Academic Research in Business and Social Sciences, vol. 4, no. 8, pp.205-214.

Freeman, R, Harrosin, J, Wicks, A, Parmar, B \& De Colle, S 2010, Stakeholder Theory: The State of the Art, Cambridge University Press, United Kingdom, UK.

Ghafoor, A \& Akhtar, N 2014, 'The impact of corporate social responsibility (CSR) on profitability of firms: a case study of fertilizer \& cement industry in Southern Punjab, Pakistan', International Journal of Development and Economic Sustainability, vol. 2, no. 4, pp. 70-79.

Griffin, J \& Mahon, J 1997, 'The corporate social performance and corporate financial performance debate: Twenty-five years of incomparable research', Business and Society, vol. 36, no. 1, pp. 5-31.

Hollos, D, Blome, C \& Foerstl K 2012, 'Does sustainable supplier co-operation affect performance? Examining implications for the Triple Bottom Line', International Journal of Production Research,vol. 50, no. 11, pp. 2968-2986.

Holme, R \& Watts, P 2000, 'Corporate Social Responsibility: Making Good Business Sense', World Business Council for Sustainable Development, Geneva.

Kang, K, Lee, S \& Huh, C 2010, 'Impacts of positive and negative corporate social responsibility activities on company performance in the hospitality industry', International Journal of Hospitality Management, vol. 29, no. 1 , pp. $72-82$.

Kumar, S, Singh, N, Kumar, V, Sunisha, B, Preeti, S, Deepali, S \& Nath, S 2008 'Impact of dust emission on plant vegetation in the vicinity of cement plant', Environmental Engineering and Management Journal, vol. 7, no. 1, pp. 31-35.

Lee, K \& Shin, D 2010, 'Consumers' responses to CSR activities: The linkage between increased awareness and purchase intention', Public Relations Review, vol. 36, no. 2, pp. 193-195.

Lee, S, Seo, K \& Sharma, A 2013, 'Corporate social responsibility and firm performance in the airline industry: The moderation role of oil price', Tourism Management, vol. 38, pp. 20-30.

Majid, K \& Abdul, M 2013, 'The Effect of Corporate Social Responsibility on Profitability and Market Share: A Case of Cement Industry of Pakistan', Academic Journal of Management Sciences, vol. 2, no. 1, pp. 4-62.

Majid, K, Abdul, M, Muhammad, Y \& Muhammad, A 2013, 'Corporate Social Responsibility and Corporate Reputation: A Case of Cement Industry in Pakistan', Interdisciplinary. Journal of Contemporary Research in 
Business, vol. 5, no. 1, pp. 843-857.

McWilliams, A \& Siegel, D 2001, 'Corporate social responsibility: A theory of the firm perspective', Academy of Management Review, vol. 26, no. 1, pp. 1117-1127.

McWilliams, A \& Siegel, D 2001, 'Corporate Social Responsibility: A Theory of the Firm' The Academy of Management Review, vol. 26, no. 1, pp. 117-127.

Mohammed, S, Ali, I \& Zahra'u A 2019, 'Determinants of corporate social responsibility in Nigerian cement industry’ Asian People Journal, vol. 1(1, pp. 164-178.

Moneva, J, Rivera-Lirio, J \& Munoz-Torres, M 2007, 'The corporate stakeholder commitment and social and financial performance', Industrial Management and Data Systems, vol. 107, no. 1, pp. 84-102.

Munaza, K, Farida, K, Shagufta, N \& Shahid H 2013, 'Impact of corporate social responsibility on the firm's financial performance', IOSR Journal of Business and Management, vol. 14, no. 5, pp. 67-74.

Murtala, Z 2017, 'The relationship between corporate social responsibility and profitability: The case of Dangote Cement Plc', Journal of Finance and Accounting, vol. 5, no. 4, pp. 171-176.

Patil, M \& Sawant, P 2014, 'corporate social responsibility, performance and sustainability reporting of shree cement company in India: A case study', Paper Presented in National Refereed Conference, “Corporate Social Responsibility: Towards New Agenda” Abhinav, International Monthly Refereed Journal of Research in Management \& Technology, vol. 3, no. 4, pp. 74-84.

Pereira, V \& Filipe J 2014, 'The board's attributes and their influence in company's performance: A review over the recent literature', International Journal of Latest Trends in Finance \& Economic Sciences, vol. 4, no. 1, pp. 691-702.

Ratner, S 2011, 'Corporations and Human Rights: A Theory of Legal Responsibility', Yale Law Journal, vol. 111, no. 3, pp.443-545.

Sapukotanage, S, Warnakulasuriya, B \& Yapa, S 2018, 'Outcomes of sustainable practices: A triple bottom line approach to evaluating sustainable performance of manufacturing firms in a developing nation in South Asia', International Business Research, vol. 11, no. 12, 89-104.

Syed, S, Bhat, G, Henah, M \& Taseen, G 2013, 'Health risks for population living in the neighborhood of a cement factory', Journal of Environmental Science and Technology, vol. 7, no. 12, pp. 1044-1052.

\#Umoren, A, Isiavwe-Ogbari, M \& Atolagbe, T 2016, 'Corporate social responsibility and firm performance: A study of listed firms in Nigeria', A paper presented at ICAN 2nd Annual International Academic Conference, Accounting and Finance, Lagos, Nigeria, 18th to 20th May 2016.

Van Marewijk, M 2003, 'Concepts and definitions of CSR and corporate sustainability: Between agency and communication', Journal of Business Ethics, vol. 44, no. 23, pp. 95-105.

Vladislav, V, Steffen, R \& Matthias, G 2019, 'Stakeholder theory: A Luhmannian perspective', Administration \& Society, vol. 51, no. 5, pp.828-849.

Wilson, M 2003, 'Corporate Sustainability:What is it and where does it come from?', Ivey Business Journal, pp. 1-6. World Business Council for Sustainable Development. (1990). Corporate social responsibility: Meeting changing expectations. World Business Council for Sust\#ainable Development, Switzerland, 37p.

Appendix

Table 4.1 Panel Data for ST, SIC, EPC, and TA

\begin{tabular}{|l|l|l|c|c|c|}
\hline COMPANY & YEAR & ST & SIC & EPC & TA \\
\hline Dangote Cement & 2009 & $202,565,699$ & 0.00 & 0.00 & $290,779,346$ \\
\hline & 2010 & $235,704,876$ & 0.00 & $620,000,000$ & $402,040,493$ \\
\hline & 2011 & $235,914,970$ & $365,949,806$ & $94,579,813$ & $526,483,412$ \\
\hline & 2012 & $298,454,068$ & $980,192,464$ & $293,529,671$ & $673,666,223$ \\
\hline & 2013 & $386,177,220$ & $1,396,352,683$ & $90,455,094$ & $844,425,313$ \\
\hline & 2014 & 391,639 & $1,013,681$ & 67,490 & $984,720,531$ \\
\hline & 2015 & 491,725 & 197,320 & 63,219 & $1,110,943$ \\
\hline & 2016 & 615,103 & $459,155,764$ & $15,252,680$ & $1,527,908$ \\
\hline & 2017 & 805,582 & $1,009,173,043$ & $10,925,004$ & $1,665,883$ \\
\hline & 2009 & $45,589,798$ & $1,650,000$ & $143,000,000$ & $87,163,067$ \\
\hline & 2010 & $43,841,325$ & $142,000,000$ & $142,000,000$ & $118,480,913$ \\
\hline & 2011 & $62,502,320$ & 0.00 & 0.00 & $152,507,595$ \\
\hline & 2012 & $87,965,224$ & $23,600,000$ & $190,000,000$ & $151,948,633$ \\
\hline & 2013 & $98,798,452$ & $58,000,000$ & $189,000,000$ & $161,081,711$ \\
\hline & 2014 & $260,810,463$ & $33,820,450$ & $226,000,000$ & $415,946,502$ \\
\hline & 2015 & $267,234,239$ & $77,344,327$ & $526,901,232$ & $453,012,397$ \\
\hline & 2016 & $219,714,112$ & 0.00 & 0.00 & $501,373,697$ \\
\hline & 2017 & $299,153,305$ & $108,700,000$ & $552,927,952$ & $587,290,284$ \\
\hline
\end{tabular}




\begin{tabular}{|l|l|c|c|c|c|}
\hline COMPANY & YEAR & ST & SIC & EPC & TA \\
\hline Ashaka Cement & 2009 & $17,193,974$ & $2,644,530$ & $111,032,256$ & $25,618,504$ \\
\hline & 2010 & $19,153,655$ & $117,854,982$ & $27,390,439$ & $28,125,125$ \\
\hline & 2011 & $20,780,234$ & $109,018,620$ & $64,776,822$ & $34,362,760$ \\
\hline & 2012 & $21,825,927$ & $131,936,966$ & $49,219,825$ & $67,325,232$ \\
\hline & 2013 & $21,694,657$ & $96,996,699$ & $37,642,562$ & $67,423,536$ \\
\hline & 2014 & $21,133,974$ & $15,919,000$ & $349,686,132$ & $71,526,871$ \\
\hline & 2015 & $17,414,895$ & 0.00 & 0.00 & $70,376,125$ \\
\hline & 2016 & $3,617,068$ & 0.00 & 0.00 & $74,629,688$ \\
\hline & 2017 & $8,831,816$ & 0.00 & 0.00 & $79,332,249$ \\
\hline
\end{tabular}

Source: Researchers' Compilation, 2020

Table 4.2 Panel Data for MVF, SIC, EPC, and MCAP

\begin{tabular}{|l|c|c|c|c|c|}
\hline COMPANY & YEAR & MVF & SIC & EPC & MCAP \\
\hline Dangote Cement & 2009 & 0.44 & 0.00 & 0.00 & $168,367,718,792.00$ \\
\hline & 2010 & 0.47 & 0.00 & $620,000,000$ & $185,892,236,016.00$ \\
\hline & 2011 & 0.45 & $365,949,806$ & $94,579,813$ & $171,597,909,566.00$ \\
\hline & 2012 & 0.38 & $980,192,464$ & $293,529,671$ & $218,288,899,845.00$ \\
\hline & 2013 & 0.38 & $1,396,352,683$ & $90,455,094$ & $373,170,071,640.00$ \\
\hline & 2014 & 0.40 & $1,013,681$ & 67,490 & $340,810,148,080.00$ \\
\hline & 2015 & 0.42 & 197,320 & 63,219 & $289,688,625,868.00$ \\
\hline & 2016 & 0.48 & $459,155,764$ & $15,252,680$ & $296,487,788,322.00$ \\
\hline & 2017 & 0.53 & $1,009,173,043$ & $10,925,004$ & $391,931,670,292.00$ \\
\hline & 2009 & 0.50 & $1,650,000$ & $143,000,000$ & $89,297,600,119.00$ \\
\hline & 2010 & 0.59 & $142,000,000$ & $142,000,000$ & $122,165,120,162.00$ \\
\hline & 2011 & 0.63 & 0.00 & 0.00 & $129,819,200,173.00$ \\
\hline & 2012 & 0.55 & $23,600,000$ & $190,000,000$ & $175,683,648,234.00$ \\
\hline & 2013 & 0.42 & $58,000,000$ & $189,000,000$ & $345,184,000,460.00$ \\
\hline & 2014 & 0.58 & $33,820,450$ & $226,000,000$ & $366,669,612,127.00$ \\
\hline & 2015 & 0.61 & $77,344,327$ & $526,901,232$ & $440,614,514,955.00$ \\
\hline & 2016 & 0.50 & 0.00 & 0.00 & $224,436,057,300.00$ \\
\hline & 2017 & 0.73 & $108,700,000$ & $552,927,952$ & $250,296,559,591.00$ \\
\hline & 2009 & 0.48 & $2,644,530$ & $111,032,256$ & $23,091,250,000$ \\
\hline & 2010 & 0.43 & $117,854,982$ & $27,390,439$ & $52,771,468,750$ \\
\hline & 2011 & 0.45 & $109,018,620$ & $64,776,822$ & $25,305,820,312.50$ \\
\hline & 2012 & 0.30 & $131,936,966$ & $49,219,825$ & $40,198,183,593.70$ \\
\hline & 2013 & 0.30 & $96,996,699$ & $37,642,562$ & $47,006,121,093.70$ \\
\hline & 2014 & 0.28 & $15,919,000$ & $349,686,132$ & $49,044,023,437.50$ \\
\hline & 2015 & 0.25 & 0.00 & 0.00 & $26,918,226,562.50$ \\
\hline & 2016 & 0.27 & 0.00 & 0.00 & $26,918,226,562.50$ \\
\hline & 2017 & 0.28 & 0.00 & 0.00 & $38,249,859,375.00$ \\
\hline
\end{tabular}

Source: Researchers' Compilation, 2020 